\title{
Advocate or Expert: In Search of an Alternative to "We versus They" Mentality
}

\begin{abstract}
In this article, the author interrogates the "we-versus-they mentality" which divides refugee advocates from hosting governments and their representatives. The author demonstrates how this bifurcation operates in the context of the NGO Doctors of the World. Physicians and mental health professionals provide volunteer services, assessing and documenting evidence of torture and maltreatment. The author argues that there is a misconception amongst government representatives that the documentation is not objective, and that the NGO advocates on behalf of its clients irrespective of whether the applicant is agenuine torture survivor. This misperception assumes that experts cannot also be advocates, and denies what is in fact a shared goal between refugee advocates and government representatives, that is, that those who have a well-founded fear of persecution receive adequate protection. Only recognizing this shared goal will break down the "we-versus-they" mentality.
\end{abstract}

\section{Résumé}

Dans cet article, l'auteur remet en question la mentalité « nous-contreeux " qui sépare, d'une part, les défenseurs des réfugiés, et de l'autre, les gouvernements hôtes et leurs représentants. L'auteur démontre comment cette bifurcation se manifeste dans le cas de l'ONG Médecins du monde. Des médecins et des professionnels de santé mentale fournissent des services volontaires pour évaluer et documenter des signes de torture et de mauvais traitements. L'auteur soutient qu'il existe chez les représentants gouvernementaux une croyance erronée

Maki Katoh is Programme Coondinator, Human Rights Project Doctors of the World, New York.

\section{Maki Katoh}

que cette documentation n'est pas objective et que l'ONG se place en position de défenseur de ses clients quel que soit le cas, que le requérant soit réellement un rescapé de la torture ou non. Cette fausse perception suppose que les experts ne peuvent être aussi défenseurs, et refuse d'admettre ce qui est en fait un objectif partagé entre défenseurs des réfugiés et représentants gouvernementaux, c'à-d. s'assurer que ceux qui craignent avec raison d'être persécutés reçoivent une protection adéquate. Le démantèlement decette mentalité « nous-contreeux » passe par la reconnaissance de cet objectif partagé.

\section{July 31, 2000}

Nine days of lectures and workshops at York University, Toronto, which took place in June 2000, have conveyed a number of messages to those who work with refugees around the world. One such message, which repeatedly came up throughout the Summer Course, was that people should move away from a "we versus they" pattern of thinking. "We" are the Westerners, the North, the developed, theintellects, and the helpers. "They" are the nonWesterners, the South, the under-developed, the primitive, and the helpless refugees. This fundamental mentality, consciously or not, appears to be still predominant certainly among the general public, and sometimes even among those who work with refugees to this day. The participants in the Summer Course, audience and lecturers alike, had to constantly remind themselves to avoid such a mentality in order to think of the humanity as one, enabling the international community to strive for protection of human rights for all.

However, there was another "we versus they" mentality that existed throughout the SummerCourse which was not readily addressed. "We", in this instance, are the aid workers, the NGOs, the advocates, and all those who are supposedly on the "refugees' side." "They", in turn, are the hosting governments and their representatives, especially in the countries by which refugees and refugees-to-be are systematically rejected to resettle and their rights constantly abused. Fortunately the Summer Course took place in Canada, which is often praised for fairer practice in aiding refugees, and thus the governmental representatives who were participating in the Course were spared extreme criticism. Even then, cynical comments, disapproving statements, and encouragement to improve the system were periodically made toward those who work in the government system. "We" are trying to help refugees but "our" work is made difficult because of "their" policies and lack of "their" will to help refugees.

This second sense of "we versus they" mentality is even more amplified in the context of work with asylum applicants, those who arrive at host countries without internationally recognized refugee status. In the work of Doctors of the World's Human Rights Clinic project, which provides medical and psychological evaluation for torture survivors applying for asylum in the United States in order to help them present their cases fully, the staff and the volunteers are quite often lured in to this "we versus they" mentality. "We" are constantly insisting that asylum applicants be treated as human beings and that their basic human rights be respected. On the other side of the struggle, "they" are seemingly and persistently trying to deny basic human rights to asylum applicants by detaining them in prison-like detention centers for an extended period of time or by denying their access to employment, social assistance, or adequate medical care. In order to move away from this "we ver- 
sus they" mentality, the volunteer physicians and mental health professionals are constantly reminded that their role is that of experts, not advocates.

In the volunteer work for Doctors of the World, physicians and mental health professionals are requested on a pro bono basis to conduct physical or psychological evaluation of torture survivors who come to the United States and apply for asylum. When volunteers find that the asylum applicants' stories regarding their past maltreatment are consistent with the physical or psychological evidence, the volunteers are requested to document such consistencies. The document then becomes objective evidence to support the applicants' claims, and often heightens the chances of the applicants' obtaining asylum. The volunteers are not requested to write any document should they find no medical or psychological evidence in their evaluation.

There are two levels of advocacy activities involved in this project for volunteers. When volunteers participate in the project, it is often because they would like to help those whose basic human rights have been violated. This is a legitimate motivation, and that over $85 \%$ of Human Rights Clinic clients who have had their cases adjudicated have been recognized as genuine torture survivors by the United States Government and granted asylum. Volunteers are rightly under the impression that most of the time they are helping those who have survived torture and seeking safe haven. The volunteers' action to take part in this project itself is an act of advocacy for the promotion of universal human rights.

Secondly, it is in support of asylum applications that volunteers write documents. Because the torture survivors seeking asylum in the United States often have little or no evidence but their scarred bodies and broken spirits to prove their stories, the documents volunteers provide may be the only objective evidence applicants can secure to support their cases. The document can be strong or weak depending on the amount of physical evidence, psychological symptoms, and applicants' memories of the past persecution. However, since there is no clinical way to disprove that applicants have been tortured, documents volunteers provide can hardly be detrimental to the asylum application. ${ }^{1}$ By providing a clinical affidavit, therefore, volunteers are advocating for applicants' right to seek asylum and lead a safe and productive life. When volunteers do not find any medical or psychological evidence to support asylum applications, they may decline to provide an affidavit, and thus choose not to advocate.

The above two aspects of advocacy are integral parts of the Human Rights Clinic project, and do not distract from the premise that our volunteers are providing objective medical expertise. However, there is a popular misperception on the government side that volunteers have already decided the asylum applicant they are seeing is indeed a torture survivor before they even start gathering clinical evidence. Furthermore, there is a misperception that volunteers will support an applicant's claim at any cost even if they find little clinical evidence. As a result, there are often attempts to dismiss volunteers' affidavits as documents prepared by advocates who are blindly trying to help asylum applicants regardless of the clinical facts. "They" see "us" as blind advocates instead of as professionals with expert knowledge.

There are two fallacies involved in this pattern of thinking. The first fallacy is the notion that advocates cannot be experts and vice versa. The second is that "we" are aiming to do something different from what "they" are aiming to do.

Because volunteers are often considered as human rights advocates in the broad sense as explained above, they are frequently labelled as such. This, however, does not mean that volunteers are advocating for each individual asylum applicant. Those who support abolition of torture worldwide do not necessarily favour all those who claim that they have suffered torture. If volunteers conclude that the applicants ex- hibit clinical evidence consistent with their stories of past persecution, volunteers usually decide to advocate in the second sense by providing affidavits in support of the asylum application. If they decide to advocate, however, that decision is based on their professional findings and expert opinions. Volunteers are both medical professionals and advocates for universal human rights simultaneously. Their expert opinions are not undermined because of their opposition to human rights violations but rather their support for any specific individual is based on their expert opinions.

The second fallacy is even more critical to overcome in order to manage the "we versus they" mentality. I believe it is useful to return to the spirit of international law regarding refugees and question what "we" and "they" are both trying to accomplish. A series of international treaties and conventions in the past half-century has set an international norm of what a refugee is, and the United States has recognized such standards and incorporated their essence into its immigration laws. The nation has also supported resettlement of internationally recognized refugees to American soil and provided assistance. However, there are those who cannot go through the official refugee recognition system provided by the United Nations High Commission for Refugees before they arrive at the country where they seek asylum. Without the internationally recognized refugee status, the asylum applicants in the Unites States have to navigate the American immigration system and strive for the recognition to have the same type of fear for persecution in their native lands as refugees are acknowledged to have: a "well-founded fear of persecution" on account of "race, religion, nationality, membership in a particular social group or political opinion."

The United States government, like any other refugee hosting country, has a set of rules to screen asylum applicants at its border and to determine which applicants are worthy of recognition as refugees. Unfortunately, this determination process in the United States has 
often been criticized as adversarial. Moreover, conditions inside the detention centers in the New York area have been repeatedly documented to be overcrowded, with little medical attention, ${ }^{2}$ tight rules for parole, excessive telephone charges, and inadequate quantities of food. ${ }^{3}$ These reports have created a general sense of distrust among NGOs working with refugees and asylum applicants in the area as to whether the government is genuinely trying to seek justice or merely attempting to drive as many applicants as possible back to their home countries regardless of the validity of their stories. The set of international norms regarding refugees which the United States has committed itself to or incorporated into its immigration laws, however, give a clear guidance as to what should be the goal both "we" and "they" strive for.

The spirit of the international laws regarding refugees states:

A person is a refugee within the meaning of the 1951 Convention as soon as he fulfils the criteria contained in the definition. This would necessarily occur prior to the time at which his refugee status is formally determined. Recognition of his refugee status does not therefore make him a refugee but declares him to be one. He does not become a refugee because of recognition, but is recognized because he is a refugee. ${ }^{4}$

Since there will inevitably be people who will try to be recognized as refugees even when they do not meet the internationally accepted criteria, it is certainly important for any countries accepting responsibilities of identifying refugees to have a sound screening system in place.

However, the aim of the process should be designed to ensure that those who have a well-founded fear of persecution receive adequate protection and assistance to lead a safe life, as opposed to testing who may be manipulating the system. If the process is used to identify who are manipulating the system, then "their" aim will be to reveal any holes in the stories of applicants and discredit any organizations or individuals that are trying to support applicants' cases and that are potential collaborators in manipulating the system. Such process is adversarial by nature. "We" may thus become tempted to declare the entire system as malfunctioning or call upon the media to aggressively report on cases where the system has failed, resulting in a hostile environment. If the process is used to distinguish genuine claims of persecution from those that are not, however, "their" aim will be to collect any and all evidence to fairly assess the credibility of each asylum applicant. This will also be "our" aim, and thus the difference between "we" and "they" disappears. Objective medical and psychological evaluation that determines the consistency of physical and psychological evidence and applicants' stories can be respected as an extremely useful piece of the puzzle in understanding a particular applicant's asylum claim.

Recognizing the shared goal in the American asylum process is the first step in overcoming the "we versus they" mentality. Based on this foundation, there will be a mutual respect between "we", the aid workers, the NGOs, the advocates, and all those who are supposedly on "refugees' side"; and "they", the hosting governments and their representatives. The experts' role will be clearly identified and recognized. "They" become a part of "us", and we as a whole can work to advocate for the protection of universal human rights.

\section{Notes}

1. There may be cases where clinical interviews demonstrate that clients can pose potential dangers to others, and such conclusions may be used against clients' application for asylum. Such cases are extremely rare, however, and do not prevent clinical affidavits from providing credible evidence of past persecutions.

2. Lajoie, R., In the land of the free: After a twoyear ordeal, U.S. grants asylum to Yudaya Nanyonga, Amnesty Action, Fall 1999, pp.6-7.

3. Smothers R., Asylum-seekers are confined to dormitories after protest, New York Times, Oct. 1, 1999.

4. UNHCR, Handbook on procedures and criteria for determining refugee status: Under the 1951 Convention and the 1967 Protocol relating to the Status of Refugees, UNHCR, Geneva, 1992, p.33.

\section{Refugee Rights: Report on a} ComparativeSurvey By James C. Hathaway and John A. Dent

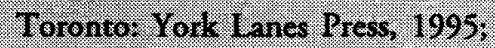
ISINH I-55014.-266-6. 82 pagest 4.1. 1.95

Are visa controls intended to keep rofugees from real Ching an asylum couniny legaln Can asylum seekers legitimately contest conditions of actention? At what poim do refigees have he right to wonk, or to Clain so hal assistanoe?

These are a mong the many issues addressed by Hivfugea Fights. Repont on a Componotive Survey, a ground breaking analysis of the human rights of refugees around the world. Working in collaboration with thirty renowred legal experts from Europo. Africa. Asia, Oceamia. Nowth America, and Latin America. Professor James. Hathaway. Osgoode Hall Law School, York Universily, and john Dent, Senior Research Associate, hitemational Refuger INGhis Project. Osgoode Mall Law School, York University. analyze tho international legal instruments that set the human rights of refugees. By grounding their analys sis in real Wfo challenges facing refugeds today. Hathaway and Dent have produced a book as valuable to activists as to scholars. Refugee Rights will provoke debate on the adequacy of the intomational refugee rights regime. It is essential reading for everyone concemed to comiter threats to the human agrits of rotugens.

Arentiblefrom:

Centre for Iefugee Studies. Fax: $(416) 736=5837$ Bmall refuge@ ayorku.ca 